\title{
Information Transparency, Debt and the Cost of Equity Capital: Evidence from China
}

\author{
Hui-Cheng Yu ${ }^{1}$, Bor-Yuan Tsai ${ }^{2}$, Beiling $\mathrm{Ma}^{3, *}$ \\ ${ }^{1}$ School of Finance and Accounting, Fuzhou University of International Studies and Trade, China \\ ${ }^{2}$ Department of Accounting Information, Aletheia University, Taiwan \\ ${ }^{3}$ School of Tourism Management, Hunan University of Technology and Business, China
}

Copyright $\bigcirc 2019$ by authors, all rights reserved. Authors agree that this article remains permanently open access under the terms of the Creative Commons Attribution License 4.0 International License

\begin{abstract}
This study adopted the signalling theory perspective to explore the effect of information transparency on the cost of equity capital among enterprises in China. Variables of information transparency and debt ratio were used to examine their influence on the cost of equity capital of enterprises in China between 2014 and 2015. The empirical results revealed that information transparency negatively affected the cost of equity capital, regardless of examining all observations simultaneously or examining the samples from 2014 and 2015 separately. However, the effect observed in 2014 was non-significant. In addition, debt positively moderated the effect of information transparency on the cost of equity capital. The results revealed that investors of the capital market paid attention to both financial and nonfinancial information disclosed by enterprises. This finding should be of great value to enterprise managers, supervisors, and decision-makers in financial or socioeconomic systems similar to that of China. Previous relevant studies have rarely explored emergent economies in socialist systems. The empirical results of this study facilitated reinforcing the research gap regarding how enterprises in socialist countries reduce their cost of equity capital amidst the economic development therein.
\end{abstract}

Keywords Information Transparency, Cost of Equity Capital, Signalling, China

\section{Introduction}

Competitions in the global business environment and demand for financial funds are becoming increasingly intensive, in particular for emerging socialist economies such as China. The One Belt One Road Initiative and economic reforms in China have led to the uneven distribution of financial funds (Feng, 2017), possibly allowing some enterprises to easily meet their cost of capital requirements in a less costly manner, while causing other enterprises to acquire such requirements at a high cost or even preventing them to achieve the required cost of capital for business operations. This raises the question of whether the uneven distribution of financial funds is caused by the level of information transparency disclosed by enterprises.

Previous studies have revealed that disclosure quality and capital funds are negatively correlated (e.g. Core, 2001; Diamond and Verrecchia, 1991; Healy et al., 1999; Chen and Hsu, 2008; Mangena et al., 2016) because information disclosure sustains the stability of the cooperation relationship between enterprises and investors (Healy and Palepu, 2001). Specifically, enterprises with high level of information disclosure can lower the information asymmetry between managers and stakeholders to reduce the cost of equity capital. This phenomenon reflects a basic concept regarding information disclosure and equity capital cost (e.g. Verrechia, 2001) that has yet to be agreed upon among scholars (Botosan, 1997), some of whom have reported research results with different perspectives (e.g. Boujelbene and Affes, 2013; Espinosa and Trombetta, 2007). The inconsistent research results might be derived from the interference of other factors - such as liability - because risks induced by liabilities might not be reduced through information disclosure in capital markets.

On the basis of previous studies, problems concerning information disclosure, liability, and equity capital cost are crucial topics in financial accounting literature (e.g. Botosan, 1997; Francis et al., 2005) that have received the attention of the academia and industry. However, the relationships among information transparency, liability, and equity capital cost, particularly in emerging socialist economies such as China, have not been thoroughly verified yet. Consequently, the present study aimed to explore the influences of information transparency and 
liability on the equity capital cost of enterprises in China, an emerging socialist market economy.

This study contributes to the research fields of information transparency, liability, and equity capital cost in the following two aspects. First, we directly investigated the influences of corporate information transparency on the cost of equity in an emerging socialist market economy, thus extending the research horizon of information transparency and the cost of equity. In addition, we determined that the influences of information transparency on the cost of equity vary with the capital market reforms in China. Second, we identified evidence confirming that liability ratio positively moderated the effect of information transparency on the cost of equity. This evidence indirectly verified that liability ratios in Chinese enterprises are excessively high and in turn influence their cost of equity, a finding that previous studies have seldom reported. The results of this study reflect crucial viewpoints on the relationship between information disclosure and cost of equity, providing meaningful information for subsequent policy-making and practice.

\section{Background}

\subsection{Signalling Theory}

Signalling aims to obtain information regarding capital markets to alleviate the extensive asymmetry between economic and social information (Spence, 2002). In other words, signalling theory mainly focuses on signals and feedback to examine the receiver's response. In addition, signal quality (i.e. quality of the disclosed information) contains the special implications of disseminating information such as reputation and fame (e.g. Certo, 2003) and generates positive corporate benefits (e.g. Mishra and Suar, 2010).

The signalling theory perspective aims to lower information asymmetry and avoid adverse selection. Therefore, signal validity (i.e. signal observability) is the key factor determining the influences of an enterprise's information transparency on its corporate performance. Previous studies (e.g. Diamond and Verrecchia, 1991; Healy et al., 1999; Chen and Hsu, 2008) have verified that information transparency is negatively and positively associated with cost of equity and corporate performance, respectively. Signal observability denotes that information can be easily deciphered by the receivers. For example, the financial and nonfinancial information disclosed by enterprises may not reflect on the cost of equity when the content of the disclosed information cannot be easily interpreted and compared by external stakeholders. Contrarily, the cost of equity may be influenced when the content of the disclosed financial and nonfinancial information can be easily interpreted and compared. Therefore, a high level of information transparency enables an enterprise to achieve a low cost of equity and therefore favourably demonstrate its competitive advantages. This study employed the perspective of signalling theory and relevant literature on cost of equity to construct its theoretical framework (Figure 1).

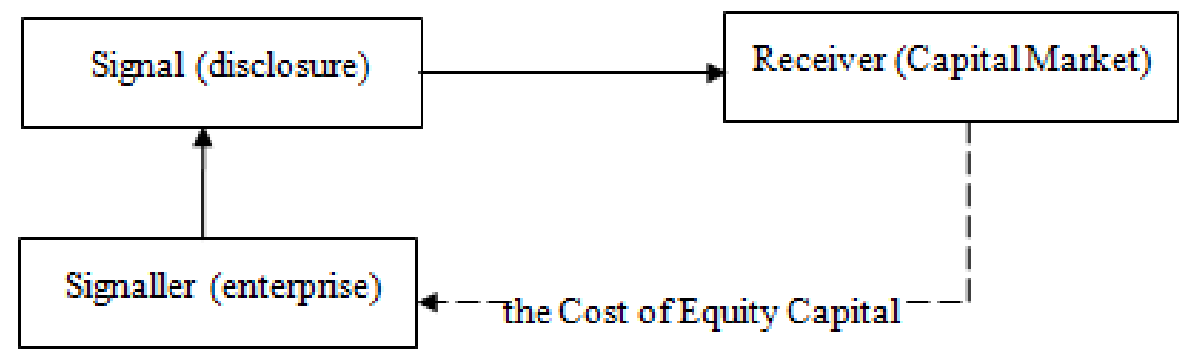

Figure 1. The connection between disclosure and the cost of equity capital 


\subsection{Characteristics of the Capital Market in China and the Cost of Equity Capital}

The capital development process in China has generated some unique characteristics, which are different from the characteristics in most of the developed capital markets worldwide. For example, the initial goal of China's capital market development was not to elevate capital allocation efficiency but to increase the convenience of state-owned enterprises and politically-associated companies when conducting external financing. Therefore, the capital market in China may not be able to offer sufficient funds for growing or innovative companies. In addition, the insufficient number of institutional investors and financial analysts in China's stock market, along with the difficulty in acquiring the information controlled by managerial executives, frequently leads to unreasonable transaction behaviours among investors (e.g. Eccher and Healy, 2000; Yeh and Lee, 2000). Another characteristic of China's capital market is that the stock market exhibits high turnover and excessive speculation among retail investors (Bailey et al., 2009; Allen et al., 2012).

Previous studies have indicated that capital market development commonly reduces the cost of equity through improvements in liquidity supplies, external monitoring, and information disclosure and risks. (1) Liquidity supply: capital market development has increased liquidity supplies to reduce the impacts exerted by companies that depend on external financing or demand high liquidity (e.g. Raddatz, 2006; Hasan et al., 2009), thereby elevating capital allocation efficiency (e.g. Wurgler, 2000). (2) External monitoring: financial development encourages investors to search for information and facilitate the development of other external supervision measures. Therefore, strengthening external supervision (e.g. evaluation system for information transparency) can suppress management opportunism, lower agency costs, and eventually reduce the cost of equity (Healy and Palepu, 2001; Ashbaugh-Skaife et al., 2006). (3) Information disclosure: participants in the capital market (i.e. investors) encounter increasingly fierce competitions and have stronger motivations to seek for private messages and transactions (Grossman and Stiglitz, 1980; Holmstrom and Tirole, 1993). In other words, disclosure is conducive to reducing information asymmetry between managers and investors (Holden and Subrahmanyam, 1992; Foster and Viswanathan, 1993), mitigating the problem of adverse selection, and eventually reducing enterprises' cost of equity (Verrechia, 2001; Diamond and Verrechia, 1991). (4) Risks: the quality of information disclosed by enterprises is beneficial in decentralizing idiosyncratic risks (e.g. Yu et al., 2017) and in turn lowering enterprises' cost of equity.

Previous studies have indicated that information transparency is a key factor influencing the cost of equity in the capital market. For example, Prodhan and Harris
(1989), Lang and Lundholm (1996), and Healy and Palepu (2001) have reported that increasing information disclosure can reduce information asymmetry and in turn lower the cost of equity of an enterprise. Francis et al. (2005) also stated that enterprises depending on external financing may expand the scope of their information disclosure because high transparency can lower the cost of equity capital. Specifically, a high level of information transparency reduces investors' uncertainty when making investing decisions, thereby decreasing the cost of equity (Clarkson et al., 1996). However, some studies have proposed opposite viewpoints. For example, Boujelbene and Affes (2013) and Espinosa and Trombetta (2007) have reported evidence disapproving the negative relationships between disclosure quality and the cost of equity capital. On the basis of the aforementioned literature, this study was conducted in the context of reforms and sustainable development in China's capital market to infer that promoting corporate information transparency can reduce information asymmetry. Accordingly, the following hypotheses are proposed.

$\mathrm{H} 1$ : Information transparency negatively influences the cost of equity.

Liability is a critical capital cost for enterprises. For enterprises, liability is an important piece of information to investors or capital markets and is a key to whether an enterprise can meet low cost of equity. Therefore, an enterprise that depends heavily on liability financing will strive to release its corporate information (e.g. Clarkson et al., 2004; Roberts, 1992), so as to communicate with its creditors and potential investors, thereby attempting to attain low cost of equity capital. Previous studies have indicated that information disclosure level is negatively associated with the liability ratio (e.g. Brammer and Pavelin, 2008; Yu et al., 2017), whereas some studies (e.g. Roberts, 1992) have indicated that the level of information disclosure is positively associated with the liability ratio. On the basis of the aforementioned literature, we inferred that compared with information transparency, greater emphasis should be placed on the liability ratio because liability represents instant, visible, and unavoidable risks, in particular for markets such as China, where most enterprises are associated with a high ratio of liability (China Worker 2017). Therefore, we examined the cost of equity capital in Chinese enterprises to confirm whether the ratio of liability influenced corporate information transparency. $\mathrm{H} 2$ was proposed accordingly:

$\mathrm{H} 2$ : An enterprise's liability ratio positively moderates the relationship between information transparency and the cost of equity.

\section{Method}

\subsection{Data Sample}

The information transparency variables employed in 
this study were derived from "Annual Report on China's Public Transparency" published by Social Science Academic Press, which incorporated data from 2014 to 2016. However, only the data from 2014 to 2015 were selected in this study because Social Science Academic Press considerably modified the method and assessment of information transparency evaluation in 2016, wherein the evaluation results differed considerably compared with those in 2014 and 2015. Consequently, the data in 2016 cannot be merged with those in the preceding two years. A total of 400 observations were collected in 2014 and 2015, among which 191 observations were excluded because they contained information from unlisted companies, and 93 observations were excluded because of incomplete data; this yielded 116 observations in total. The research period spanned from 2014 to 2015 , and all of the financial variables were obtained from the China Stock Market \& Accounting Research (CSMAR) database.

\subsection{Empirical Model}

This study explored the influences of information transparency on the cost of equity capital, with (1) presenting the empirical model:

$$
\begin{array}{r}
\mathrm{COC}_{\mathrm{i}, \mathrm{t}}=\alpha_{1}+\beta_{1} \mathrm{IT}_{\mathrm{i}, \mathrm{t}}+\beta_{2} \mathrm{RISK}_{\mathrm{i}, \mathrm{t}}+\beta_{3} \mathrm{BM}_{\mathrm{i}, \mathrm{t}}+\beta_{4} \mathrm{SIZE}_{\mathrm{i}, \mathrm{t}}+\beta_{5} \mathrm{LEV}_{\mathrm{i}, \mathrm{t}}+ \\
u_{\mathrm{i}, \mathrm{t}}
\end{array}
$$

For $i=1,2, \ldots, 161$; and $\mathrm{t}=2014$ and 2015

Where COC denotes the cost of equity capital. Many studies have explored models for estimating the cost of equity capital (e.g. Claus and Thomas, 2001; Gebhardt et al., 2001; Gode and Mohanram, 2003; Easton, 2004), and recent studies (e.g., Mangena et al. 2016) have indicated that the model proposed by Easton (2004) is more robust compared with other models. Therefore, the present study also employed the PEG model introduced by Easton (2004, p. 81). Specifically, COC is measured using the following equation:

$$
\mathrm{COC}=\frac{\sqrt{\left(\mathrm{EPS}_{2}-\mathrm{EPS}_{1}\right)}}{\mathrm{P}_{0}}
$$

where $\mathrm{EPS}_{2}$ denotes the 2-year-ahead earnings per share predicted by analysts; EPS $_{1}$ denotes the 1-year-ahead earnings per share predicted by analysts; and $\mathrm{P}_{0}$ denotes the current share price. The PEG model possesses two key limitations. First, $\mathrm{EPS}_{1}$ and $\mathrm{EPS}_{2}$ must be positive numbers; and second, $\mathrm{EPS}_{2}$ must be larger than $\mathrm{EPS}_{1}$ (e.g. Easton, 2004; Lee et al., 2006). IT refers to the data of information transparency acquired through manually compiling information in "Annual Report on China's Companies Public Transparency". In this evaluation system, information disclosure is rated using 98 indices (items) in five dimensions (i.e., time, content, media, form, and quantity). The time dimension consists of 4 items, including the annual report release time, CSR report release time, quantity of negative messages, and amount of corporate news. The content dimension consists of 59 items focusing mainly on environmental management, corporate governance, customer satisfaction, and employee benefits (see the Blue Book of Companies' Public Transparency - Annual Report on China's Companies' Public Transparency (2014 2015) p.7-11). The media dimension consists of 20 items, which mainly evaluate the release time of various reports (i.e., annual financial statements and CSR reports) and the online accessibility of these reports (see the Blue Book of Companies' Public Transparency-Annual Report on China's Companies' Public Transparency (2014 2015) p.11-12). The form dimension consists of 10 items. The evaluation in this dimension focuses mainly on the language used for reporting (e.g., Chinese, English) and whether each report has been audited (see Blue Book of Companies' Public Transparency-Annual Report on China's Companies' Public Transparency (2014 2015) p.13). The quantity dimension consists of 5 items, namely the amount of corporate news, amount of Baidu Search hits containing the company full name, amount of Baidu Search hits containing the abbreviated name of the company, amount of company-related data in the China Core Newspapers Full-text Database (CNKI), and amount of quantitative information disclosure. Different scales are used for different dimensions. For the time dimension, the scale ranges between -0.5 and 1 . For the content dimension, 1 is used to denote information disclosure, and 0 is used to denote no information disclosure; the scale ranges between 0 and 2 for evaluating participating domestic or foreign organizations. For the media dimension, 1 is used to denote information disclosure, and 0 is used to denote on information disclosure. For the form dimension, the scale ranges between -0.2 and 1 . For the quantity dimension, the scale ranges between 0.3 and 1 . The total score for the 98 items in five dimensions will add up to 100; RISK refers to the market risk, with the Beta serving as the proxy variable; and $\mathrm{BM}$ refers to the book-to-market ratio, which is measured by dividing the book value of common stock at the end of the year with the market price of common stock at the end of the year. Previous studies (e.g. Fama and French, 1992; Rosenberg et al., 1985) have reported that the book-to-market ratio is one of the factors affecting stock returns. SIZE refers to company size, which is derived from the natural logarithm of the operating revenue; and LEV refers to the ratio of liability.

This study explored whether the ratio of liability moderated the relationship between information transparency and the cost of equity capital, using the model presented in (2):

$$
\begin{array}{ccc}
\mathrm{COC}_{\mathrm{i}, \mathrm{t}}=\alpha_{1}+\beta_{1} \mathrm{IT}_{\mathrm{i}, \mathrm{t}}+\beta_{2} & \mathrm{LEV}_{\mathrm{i}, \mathrm{t}}+\beta_{3}(\mathrm{IT} \times \mathrm{LEV})_{\mathrm{i}, \mathrm{t}}+\beta_{4} \mathrm{RISK}_{\mathrm{i}, \mathrm{t}} \\
+\beta_{5} & \mathrm{BM}_{\mathrm{i}, \mathrm{t}}+\beta_{6} \operatorname{SIZE}_{\mathrm{i}, \mathrm{t}}+u_{\mathrm{i}, \mathrm{t}}
\end{array}
$$

where (2) incorporates an interaction term $(\mathrm{IT} \times \mathrm{LEV})$ to examine how the ratio of liability moderates the effect of 
information transparency on capital of equity; hence, this model was used to validate $\mathrm{H} 2$. If the $\beta_{3}$ coefficient of the interaction term is positive and significant, then $\mathrm{H} 2$ is supported.

\section{Empirical Results}

Table 1 presents the descriptive statistical results of each variable. We determined that the mean $\mathrm{COC}$ value is 0.111 , which is consistent with the results of studies on the international and China's capital markets (e.g. Mangena et al., 2016; Kim et al., 2015). The largest and smallest values of COC are respectively 0.845 and 0.033 , indicating that great variations existed in the costs of equity financing among the observed companies. The mean of information transparency (IT) is 44.815, indicating that the information transparency level of the observed companies is moderately low, a finding similar to those of previous studies (e.g. Lam and Du, 2004; Jin and Myers, 2006). The mean of market risk (RISK) is 1.065 , showing that the risk level of the observed market (i.e. China) is greater than the capital market risk in Western countries (e.g. Mangena et al., 2016). The mean book-to-market ratio (BM), company size (SIZE), and liability ratio (LVE) are respectively $0.858,10.947$, and 0.679 , revealing that on average, liability accounted for approximately $67.9 \%$ of the total assets owned by the observed companies. This finding implied that the source of capital possessed by the observed companies was mainly derived from external loans, reflecting that these companies need to acquire low cost of equity capital to sustain their corporate operation.

Table 2 presents the pairwise correlation between the variables. Except for the relatively large correlation coefficients of SIZE in relation to IT (0.703), BM (0.595), and LEV (0.584), the correlation coefficients between other pairs of variables are small. The variance inflation factors of SIZE (2.984), IT (2.098), BM (1.714), and LEV (1.630) are low, further verifying the absence of collinearity among variables; this finding confirmed that all variables explored this study were independent of each other.

Table 1. Descriptive statistics

\begin{tabular}{|c|c|c|c|c|c|}
\hline Variable & Obs & Mean & Std. deviation & Min & Max \\
\hline COC & 116 & 0.111 & 0.140 & 0.001 & 0.845 \\
\hline IT & 116 & 44.815 & 18.331 & 9.850 & 77.800 \\
\hline RISK & 116 & 1.065 & 0.236 & 0.437 & 1.644 \\
\hline BM & 116 & 0.831 & 0.200 & 0.177 & 1.297 \\
\hline SIZE & 116 & 10.947 & 1.005 & 9.065 & 13.291 \\
\hline LEV & 116 & 0.679 & 0.201 & 0.027 & 0.945 \\
\hline
\end{tabular}

Notes: COC denotes the cost of equity capital; IT denotes information transparency; RISK denotes the market risk, with the Beta serving as the proxy variable; BM denotes the book-to-market ratio; SIZE denotes company size; and LEV denotes the ratio of liability.

Table 2. Pearson correlations between variables

\begin{tabular}{|c|c|c|c|c|c|c|}
\hline & COC & IT & Risk & BM & SIZE & LEV \\
\hline COC & 1.000 & & & & & \\
\hline IT & $0.155^{*}$ & 1.000 & & & & \\
\hline RISK & $-0.182^{* *}$ & $-0.381^{* * *}$ & 1.000 & & & \\
\hline BM & $0.274^{* * *}$ & $0.523^{* * *}$ & $-0.205^{* *}$ & 1.000 & & \\
\hline SIZE & $0.344^{* * *}$ & $0.703^{* * *}$ & $-0.465^{* * *}$ & $0.595^{* * *}$ & 1.000 & 1.000 \\
\hline LEV & $0.324^{* * *}$ & $0.467^{* * *}$ & $-0.262^{* * *}$ & $0.499^{* * *}$ & $0.584^{* * *}$ & 1 \\
\hline
\end{tabular}

Note: ${ }^{*} p<.1 ;{ }^{* *} p<.05 ;{ }^{* * *} p<.01$. 
Table 3. Regression results derived from all observations, 2014 observations, and 2015 observations

\begin{tabular}{|c|c|c|c|}
\hline \multirow{2}{*}{ Variable } & All observations & 2014 & 2015 \\
\cline { 2 - 4 } & Coefficient $(t$-value $)$ & Coefficient $(t$-value $)$ & Coefficient $(t$-value $)$ \\
\hline Constant & $-0.387^{*}(-1.857)$ & $-0.460^{* *}(-2.120)$ & $-0.246(0.458)$ \\
\hline IT & $-0.002^{*}(-1.750)$ & $-0.001(-0.724)$ & $-0.261^{* *}(-2.025)$ \\
\hline RISK & $-0.033(-0.562)$ & $0.136^{*}(1.752)$ & $0.055(0.480)$ \\
\hline BM & $0.074(0.934)$ & $0.032(0.253)$ & $0.006(0.131)$ \\
\hline SIZE & $0.042^{* *}(2.064)$ & $0.035(1.476)$ & $0.212(1.460)$ \\
\hline LEV & $0.127(1.655)$ & $0.082(0.958)$ & 0.232 \\
\hline Adj. $R^{2}$ & 0.130 & 0.077 & $3.995^{* * *}$ \\
\hline$F$-value & $4.445^{* * *}$ & $2.449^{* *}$ & 70 \\
\hline Obs. & 116 & 46 & \\
\hline
\end{tabular}

Notes: ${ }^{*} p<.1 ;{ }^{* *} p<.05 ;{ }^{* * *} p<.01$.

Table 3 presents the effect of information transparency on the cost of equity capital. Examining all the samples simultaneously indicates that information transparency negatively and significantly affected the cost of equity capital; hence, $\mathrm{H} 1$ is supported. This finding indicates that the effect of information transparency on the capital market in an emerging socialist market economy is consistent with those in the capital markets worldwide. In addition, we separately analysed the effect of information transparency on the cost of equity capital using samples from 2014 and 2015 and observed a notable phenomenon. Specifically, information transparency exerted a negative and non-significant effect the cost of equity capital in 2014, yet a negative but significant effect in 2015. This difference might be attributable to the capital market reforms in China, which entailed measures such as improvements in information disclosure, external supervision, and risk prevention. The change in the effect of market risk on the cost of capital from significantly positive in 2014 to significantly negative in 2015 also verified the changes in the capital market of China.

What's more, we determined that liability ratio (LEV) positively affected the cost of equity capital (Table 3 ) and investigated whether this finding reflected the signal that the cost of equity capital is relatively higher when the information transparency of an enterprise is moderated by liability ratio. To find the answer, further exploration was conducted on this finding to determine whether liability ratio exerted a positive moderating effect on the influence of information transparency on the cost of equity. As shown in Table 4 , the interaction term IT $\times$ LEV positively and significantly affected the cost of equity; hence, $\mathrm{H} 2$ is supported. The results indicate that capital markets place a greater emphasis on liability ratio than on information transparency; that is, while enterprises' information transparency is important, a greater emphasis is placed on their status of liability.
Table 4. Moderating effect of liability ratio (LEV) on information transparency (IT) and the cost of equity capital (COC)

\begin{tabular}{|c|c|c|}
\hline Variable & Coefficient & $t$-value \\
\hline Constant & -0.199 & -0.868 \\
\hline IT & $-0.002^{*}$ & -1.823 \\
\hline LEV & 0.023 & 0.212 \\
\hline IT $\times$ LEV & $0.077^{*}$ & 1.793 \\
\hline RISK & -0.013 & -0.212 \\
\hline BM & 0.133 & 1.539 \\
\hline SIZE & $0.021^{* *}$ & 2.123 \\
\hline Adj. $R^{2}$ & \multicolumn{2}{|c}{0.138} \\
\cline { 1 - 1 }$F$-value & $4.061^{* * *}$ \\
\cline { 1 - 2 } Obs. & \multicolumn{2}{|c}{} \\
\hline
\end{tabular}

Notes: ${ }^{*} p<.1 ;{ }^{* *} p<.05 ;{ }^{* * *} p<.01$.

\section{Discussion and Conclusions}

This study employed the perspective of signalling theory to investigate the effect of information transparency on the cost of equity capital among enterprises in China. In addition, the moderating effect of liability on the influence of information transparency on the cost of equity capital. The empirical results indicate that information transparency negatively affected the cost of equity in 2014 and 2015. Statistical significance was observed in all samples except for those in 2014. This finding implies that capital markets under socialist market economy (i.e. China) are gradually attaching greater importance to information disclosure, indirectly suggesting that such capital markets are gradually aligning with capital markets in Western countries, becoming relatively more internationalized, and increasing the investment ratio of foreign capital (Economic Information Daily, 2018). In addition, we determined that liability ratio positively moderated the effect of information transparency on the cost of equity capital. This evidence verifies that investors in the observed capital market (i.e. 
China) placed a greater emphasis on enterprises' liability status, possibly because liability could induce instant, visible, and unavoidable risks that could not be alleviated through information transparency.

This study also provided several evident findings relevant to the cost of equity capital for the academia and industry. Previous studies (e.g. Bailey et al., 2009; Allen et al., 2012; Eccher and Healy, 2000; Yeh and Lee, 2000) have considered that the insufficient number of institutional investors and financial analysts in China's stock market and the high turnover and excessive speculation among retail investors have led investors to place extra emphasis on corporate information. However, the present study determined that investors in the capital market paid attention to both the financial and nonfinancial information disclosed by enterprises. The empirical results should be of great value to corporate managers, supervisors, and decision-makers in countries with similar financial and social economic system. Finally, we determined that liability positively moderated the effect of information transparency on the cost of equity, indirectly verifying the high financial leverage among enterprises in China (Yao and Jin, 2016) that in turn affected their cost of equity capital.

This study had the following limitations. First, the research period spanned only from 2014 to 2015 (The Blue Book of Companies' Public Transparency-Annual Report on China's Companies' Public Transparency contains evaluation results regarding information disclosure among companies in China since 2014. This evaluation system has yet to become mature. Consequently, evaluation standards in the system have been revised heavily each year since 2016. This leads to inconsistency in evaluation results and impedes data sampling. Only the evaluation standards and results from 2014 and 2015 were relatively consistent; this period was therefore used as the sampling period of this study.), because the evaluation method for assessing information transparency changed considerably in 2016, and thus data after 2016 cannot be merged with those from 2014 and 2015. This limitation in data sampling was also a major research constraint of this study. Second, Social Sciences Academic Press is currently the only press in China that systematically and regularly publishes reports on enterprises' public transparency in China. However, the Press only evaluates the information transparency of the top 200 large enterprises in China, and thus the research results may not be applicable to enterprises of smaller scale.

\section{Acknowledgements}

The authors would like to thank the editor and anonymous referees for their useful comments and suggestions which helped us to improve the clarity of the paper. This work is supported by the State Key Program of National Natural Science of China (No. 71431006) and Natural Science Foundation of Hunan Province of China (No. 2016JJ6048).

\section{REFERENCES}

[1] Allen, F., Qian, J., Zhang, C., and Zhao, M., (2012). China's financial system: opportunities and challenges. National Bureau of Economic Research Working Papers No. 17828.

[2] Ashbaugh-Skaife, H., Collins, D.W., and LaFond, R., (2006). Corporate governance and cost of equity capital. Working Paper, University of Wisconsin at Madison.

[3] Bailey, W., Cai, J., Cheung, Y., and Wang, F., (2009). Stock returns, order imbalances, and commonality: evidence on individual, institutional, and proprietary investors in China. Journal of Banking \& Finance, 33(1), 9-19.

[4] Botosan, C.A., (1997). Disclosure level and the cost of equity capital. The Accounting Review, 72(3), 323-349.

[5] Boujelbene, M.A., and Affes, H., (2013). The impact of intellectual capital disclosure on cost of equity capital: A case of French firms. Journal of Economics, Finance and Administrative Science, 18(34), 45-53.

[6] Brammer, S., and Pavelin, S., (2008). Factors influencing the quality of corporate environmental disclosure. Business Strategy and the Environment, 17, 120-136.

[7] Certo, S.T., (2003). Influencing initial public offering investors with prestige: Signalling with board structures. Academy of Management Review, 28, 432-446.

[8] Chen, J.P., and Hsu, C.Y., (2008). The effect of disclosure level on the cost of equity capital. Soochow Journal of Economics and Business, 61, 67-108.

[9] China Worker, (2017). Five years have passed: How's the economic crisis in China? http://chinaworker.info/zh/2017/ 07/15261/ [accessed 7 January 2018]

[10] Clarkson, P.M., Li, Y., and Richardson, G.D., (2004). The market valuation of environmental capital expenditures by pulp and paper companies. The Accounting Review, 79(2), 329-353.

[11] Clarkson, P., Guedes, J., and Thompson, R., (1996). On the diversification, observability, and measurement of estimation risk. Journal of Financial and Quantitative Analysis, 31(1), 69-84.

[12] Claus, J., and Thomas, J., (2001). Equity premia as low as three percent? Evidence from analysts' earnings forecasts for domestic and international stock markets. The Journal of Finance, 56(5), 1629-1666.

[13] Core, J.E., (2001). A review of the empirical disclosure literature: Discussion. Journal of Accounting and Economics, 31, 441-456.

[14] Diamond, D.W., and Verrecchia, R.E., (1991). Disclosure, liquidity and the cost of Capital. Journal of Finance, 46(4), 
$1325-1359$.

[15] Easton, P.D., (2004). PE ratios, PEG ratios, and estimating the implied expected rate of return on equity capital. The Accounting Review, 79, 73-79.

[16] Eccher, E., and Healy, P.M., (2000). The role of international accounting standards in transitional economies. Working Paper, MIT Sloan School of Management and Harvard Business School.

[17] Economic Information Daily, (2018). Six major reforms to be welcomed in the multi-layered capitalist market. http;//jjckb.xinhuanet.com/2018-03/07/c_137020817.htm [accessed 7 March 2018]

[18] Espinosa, M., and Trombetta, M., (2007). Disclosure interactions and the cost of equity capital: evidence from the Spanish continuous market. Journal of Business Finance \& Accounting, 34(9-10), 1371-1392.

[19] Fama, E.F., and French, K.R., (1992). The cross-section of expected stock returns. Journal of Finance, 47(2), 427-465.

[20] Feng, M., (2017). China's financial sector is underdeveloped rather than over-developed. The Financial Times.http://big5.ftchinese.com/story/001073457?full=y\& archive [accessed 23 February 2018]

[21] Foster, F., and Viswanathan, S., (1993). The effect of public information and competition on trading volume and price volatility. The Review of Financial Studies, 6(1), $23-56$.

[22] Francis, J.R., Khurana, I.K., and Pereira, R., (2005). Disclosure incentives and effects on cost of capital around the world. Accounting Review, 80(4), 1125-1162.

[23] Gebhardt, R., Lee, C., and Swaminathan, B., (2001). Toward an ex ante cost of capital. Journal of Accounting Research, 39(1), 135-176.

[24] Gode, D., and Mohanram, P., (2003). Inferring cost of capital using the Ohlson-Juettner model. Review of Accounting Studies, 8(4), 399-431.

[25] Grossman, S. J., and Stiglitz, J., (1980). On the impossibility of informationally efficient markets. The American economic review, 70(1), 393-408.

[26] Hasan, L., Wachtel, P., and Zhou, M., (2009). Institutional development, financial deepening, and economic growth: Evidence from China. Journal of Banking \& Finance, 33(1), 157-170.

[27] Healy, P.M., Hutton, A.P., and Palepu, K.G., (1999). Stock performance and intermediation changes surrounding sustained increases in disclosure. Contemporary Accounting Research, 16(3), 485-520.

[28] Healy, P.M., and Palepu, K.G., (2001). Information asymmetry, corporate disclosure, and the capital markets: A review of the empirical disclosure literature. Journal of Accounting and Economics, 31(1-3), 405-440.

[29] Holmstrom, B., and Tirole, J., (1993). Market liquidity and performance monitoring. Journal of Political Economy, 101(4), 678-709.

[30] Holden, C., and Subrahmanyam, A., (1992). Long-lived private information and imperfect competition. The Journal of Finance, 47(1), 247-270.

[31] Jin, L., and Myers, S.C., (2006). R2 around the world: New theory and new tests. Journal of Financial Economics, 79, 257-292.

[32] Kim, J.B., Ma, M.L.Z., and Wang, H., (2015). Financial development and cost of equity capital: Evidence from China. China Journal of Accounting Research, 8, 243-277.

[33] Lam, S.S., and Du, J., (2004). Information asymmetry and estimation risk: Preliminary evidence from Chinese equity markets. Pacific-Basin Finance Journal, 12, 311-331.

[34] Lang, M.H., and Lundholm, R.J., (1996). Corporate disclosure policy and analyst behaviour. The Accounting Review, 71(4), 467-492.

[35] Lee, E., Walker, M., and Christensen, H.B., (2006). The cost of capital in Europe: An empirical analysis and the preliminary impact of international accounting harmonization. London, England: The Association of Chartered Certified Accountants.

[36] Mangena, M., Li, J., and Tauringana, V., (2016). Disentangling the effects of corporate disclosure on the cost of equity capital: a study of the role of intellectual capital disclosure. Journal of Accounting, Auditing \& Finance, 31(1), 3-27.

[37] Mishra, S., and Suar, D., (2010). Does corporate social responsibility influence firm performance of Indian companies? Journal of Business Ethics, 95(4), 571-601.

[38] Prodhan, B., and Harris, M., (1989). Systematic risk and the discretionary disclosure of geographical segments: an empirical investigation of US multinationals. Journal of Business, Finance \& Accounting, 16(4), 467-492.

[39] Raddatz, C., (2006). Liquidity needs and vulnerability to financial underdevelopment. Journal of financial economics, 80(3), 677-722.

[40] Robersts, R., (1992). Determinants of corporate social responsibility disclosure: an application of stakeholder theory. Accounting, Organization and Society, 17(6), 595-612.

[41] Rosenberg, B., Reid, K., and Lanstein, R., (1985). Persuasive evidence of market inefficiency. Journal of Portfolio Management, 11(1), 9-17.

[42] Spence, M., (2002). Signalling in retrospect and the informational structure of markets. American Economic Review, 92, 434-459.

[43] Verrecchia, R.E., (2001). Essays on disclosure. Journal of Accounting and Economics, 32(1-3), 97-180.

[44] Wurgler, J., (2000). Financial markets and the allocation of capital. Journal of financial economics, 58(1-2), 187-214.

[45] Yao, Y.D., and Jin, H.N., (2016). Debt in China: How to break Free from the high leverage trap. Beijing: Citic Press Group.

[46] Yeh, Y.H., and Lee, T.S., (2000). The interaction and volatility asymmetry of unexpected returns in the greater China stock markets. Global Finance Journal. 11(1-2), 129-149. 
[47] Yu, H.C., Kao, M.F., Chen, Y.C., and Tsai, B.Y., (2017).

Firm transparency and idiosyncratic risk. Economics and

Business Letters, 6(3), 81-87. 